УДК $658.003 .13(075.8)$

\author{
Войтенко К.О. \\ аспірант \\ кафедра обліку та аудиту \\ Одеська національна академія харчових технологій \\ вул. Канатна, 112, м. Одеса, Україна, 65039, witav@rambler.ru
}

\title{
ПРОБЛЕМИ ПІДВИЩЕННЯ ЕКОНОМІЧНОЇ ЕФЕКТИВНОСТІ ВИРОБНИЦТВА НА ПІДПРИЄМСТВАХ ХАРЧОВОЇ ПРОМИСЛОВОСТІ
}

Існують різні методики визначення ефективності виробництва, але вони не застосовані до харчових підприємств і до сучасних умов розвитку національної економіки. Для того щоб ефективність була науково обгрунтовано визначена, потрібно її «корегувати» з урахуванням підприємницького ризику, бажання держави захищати інвестиції та боротися з тіньовою економікою. Діяльність підприємця направлена на захист своєї фірми від дій ризиків, які загрожують ії̈ прибутковості, ефективності.

Ключові слова: ефективність виробництва, ефективність споживання харчових продуктів, інвестиційний (підприємницький) ризик.

Постановка проблеми та її зв'язок з важливими науковими та практичними завданнями. В умовах стрімкого падіння ВВП України, зростання безробіття і банкрутств підприємств значне місце займає проблема ефективності виробництва. Інтеграція у Європейський Союз, загострення економічної, військово-політичної ситуації в країні вимагає підвищення ефективності, зростання конкурентоздатності вітчизняних підприємств. При цьому виникає проблема розрахунку ефективності.

Аналіз останніх публікацій по проблемі. Незважаючи на то, що цією проблемою займались ще радянські вчені-економісти - розраховували ефективність на макрорівні, галузі, підприємства, вона залишається актуальною і сьогодні [1, с.382-383]. Хоча показник абсолютної або загальної, порівняльної ефективності присутній у науковій літературі [2, с.351-358], на практиці він мало використовується, особливо у сучасних ринкових умовах. Краще розкриває сутність розвитку народного господарства показник соціально-економічної ефективності. Але й він не завжди використовується.

Сучасні українські вчені займаються виміром та оцінкою економічної ефективності впровадження у виробництво нової техніки, нової продукції [3, с.199-225]. Безумовно, це перспективний, цікавий напрямок досліджень, але у сучасних умовах економіка країни залишається інвестиційно непривабливою. Тому здійснювати розрахунок економічної ефективності впровадження у виробництво нової техніки та продукції доцільно лише у майбутньому, коли будуть проведені реформи і народне господарство стане конкурентоздатним. Крім того, якщо у промисловості були спроби розрахувати прибутковість, ефективність виробництва, то у харчовій галузі, у АПК майже не здійснювались розрахунки у часи незалежності України. Зростання ефективності виробництва в харчовій промисловості в умовах інтеграції у Європейський Союз - головний шлях стабільного забезпечення населення продуктами харчування, конкурентоздатності АПК країни. Це зумовлює необхідність прискорити обгрунтований пошук шляхів і напрямків підвищення ефективності та інтенсивності виробництва і на цій основі підвищення життєвого рівня. На думку професора П.П. Борщевського, «складність і багатофакторність процесу підвищення ефективності виробництва, різна спрямованість їхніх складових зумовлюють необхідність оцінки і визначення не лише загального рівня ефективності та інтенсивності виробництва, а й здійснення факторного аналізу цього неоднозначного економічного явища. Органічний взаємозв'язок критеріїв ефективності та інтенсивності виробництва $є$ необхідною умовою формування комплексної оцінки рівня ефективності виробництва» [4, с.39-40].

Безумовно, ефективність безпосередньо пов'язана зі структурою АПК, асортиментом продуктів харчування, їх біологічною цінністю тощо. Ось чому, невипадково Н.Й. Басюркіна вважає, що «для розрахунку комплексної економічної ефективності всіх процесів агропромислового сектору від виробництва сільськогосподарської сировини до кінцевого споживання, є можливим і доцільним проводити їх за показниками витрат на одиницю виробленої продукції і рентабельності продукції або норми прибутку на одиницю витрат» [6, с.324]. Вона, на нашу думку, правильно розраховує комплексний показник економічної ефективності виробництва і споживання в агропромисловому секторі як суму показників економічної ефективності виробництва сільськогосподарської продукції, харчових продуктів, діяльності торгівлі та у сфері 
споживання. У той же час не до кінця зрозуміло, як автор буде розраховувати ефективність у сфері споживання і у яких показниках? У натуральних або вартісних?

Зростання цін на харчові продукти у 2014 році привело до того, що деяка м'ясна та молочна продукція для значної кількості населення стала недоступною. Це веде до підвищення захворюваності. Підвищення цін на ліки робить неможливим їх придбання і буде сприяти росту смертності. Тому ефективність споживання харчових продуктів, на нашу думку, може приводити до зростання тривалості життя і їі можна розраховувати у роках (тривалості життя), або у прирості (зниженні) ВВП від активної участі населення у виробництві.

Деякі закордонні вчені враховують, що на ефективність фермерських господарств впливають лізинг, зайнятість населення, але це не дозволяє з'ясувати, як автори [9-14] розраховують іiі в цілому? Крім того, є особливості розрахунку ефективності стосовно до тої, або іншої країни, що не дозволяє цю методику використовувати в Україні.

Все це свідчить, що ефективність виробництва недостатньо досліджена і для її визначення у харчовій промисловості, АПК і в цілому економіки України неможливо використовувати застарілі та зарубіжні методики. Їх використання повинно бути обмеженим, тому що це не завжди «цікавить» підприємців.

Формування цілей дослідження. Метою дослідження є:

- визначення вимог ефективності харчових підприємств;

- розробка механізму управління;

- 3'ясування того, які ризики чекають підприємців і як вони впливають на інвестиційну діяльність.

Виклад основних результатів та їх обгрунтування. Організаційно-економічний механізм управління ефективністю підприємства, на думку професора А.Г. Гончарука, повинен містити «мотиваційний механізм, необхідний для якісного виконання приймаючих рішень і досягнення мети підвищення ефективності» [5, с.205206]. При цьому, під загальним механізмом управління ефективністю підприємства він розуміє «сукупність організаційних структур конкретних організаційних, економічних і мотиваційних інструментів, методів управління, реалізуючи чітку послідовність дій, направлених на забезпечення безперервного та сталого процесу підвищення ефективності підприємства» [5, с.206]. На жаль, автор під мотиваційним механізмом розуміє лише «систему стимулювання персоналу» [5, с.229], яка існувала ще з радянських часів, а історія показала, що цього зовсім недостатньо.
На нашу думку, мотиваційний механізм підвищення ефективності виробництва повинен бути підкріплений відповідальністю як працівників підприємства, так і бізнесу, здатністю держави захистити підприємців. Сьогодні підприємців все більше турбує навіть не прибутковість, не ефективність, а здатність зберігати інвестиції і сам бізнес, не допускати рейдерських захоплень та інших корупційних дій проти фірми. Діяльність підприємця направлена на захист своєї фірми від дій ризиків, які загрожують її прибутковості, і сприяє рішенню основної задачі підприємництва - в залежності від ситуації вибрати $з$ декількох проектів оптимальний.

Згідно з результатами доповіді групи Всесвітнього банку за минулий рік Україна, не зважаючи на економічну та політичну кризу, покращила умови ведення бізнесу і перемістилася у рейтингу Doing Business - 2015 з 112-го на 96-е місце. У доповіді відмічається прогрес у сферах реєстрації прав власності і оподаткування - по цим двом показникам Україна покращила своє місце більше, ніж на 25 позицій.

У 2013-2014 роках Україна полегшила підприємцям сплату податків, використовуючи електронну систему подачі та сплати податків. У рамках цієї ініціативи кількість податкових платежів було зменшено з 28 до 5, а час, витрачений на їх сплату скоротився з 390 до 350 годин [7].

Незважаючи на формальне покращення ситуації у веденні бізнесу, вітчизняні підприємці не відчули цього. При складанні рейтингу експерти Всесвітнього банку враховували регуляторні покращення у країні, які далеко не завжди ідентичні реальним змінам. Вони не враховують складність «взаємодії» підприємців 3 податківцями, кількість планових, позапланових перевірок і обсяги корупції. За перше півріччя 2014 року було проведено 11996 позапланових перевірок, у той час, як при уряді В. Януковича за аналогічний період провели лише 4530 перевірок [8].

Згідно даних Федерації роботодавців, більше всього перевіряли бізнес:

- Держслужба по надзвичайним ситуаціям (105138 перевірки),

- Державна санітарно-епідеміологічна служба,

- Державна ветеринарна та фітосанітарна служба України,

- Пенсійний фонд.

Здійснення такого тиску вже привело до скорочення бізнесу. Як відмічає віце-президент Українського союзу підприємців і промисловців Юлія Дороговоз, покращення позицій України не вплине і на іiї інвестиційну привабливість: «Інвестори в першу чергу враховують реальну ситуацію, а не місце в топ-100. Ті підприємства, які вже 
зайшли в Україну, бачать, що реальність у нас інша. А ті, хто планує заходити в Україну, чекають, не позицій в рейтингах, а реальних реформ. Їх відсутність, в тому числі реформи судової системи, є для них у даному випадку, визначальним. Зараз інвестори прямо кажуть, що не готові працювати в Україні, поки та не зможе гарантувати їм захист власності і капіталів. Реформування судової системи стане для них куди більш дієвим сигналом, ніж рейтинг «Doing Business» [7].

Все це свідчить про те, що зараз практиків-підприємців та науковців цікавить не стільки ефективність бізнесу, як ризик не загубити свій капітал, стабільність в країні. Ось чому усі існуючі методики оцінки ефективності виробництва харчової промисловості необхідно доповнювати, «корегувати» з урахуванням підприємницького ризику, який безумовно «пов'язаний» з розміром прибутку і стабільності у країні, довіри до держави. Коли довіра буде досягнута можна здійснювати державні програми по енергоефективності, збереженню енергоносіїв, зменшувати залежність від Росії, залучати для цього вітчизняний та іноземний бізнес. Україна має значний потенціал у вико- ристанні біопалива, сонячної енергії. Це буде підвищувати ефективність виробництва не тільки АПК, а й всього народногосподарського комплексу країни.

Висновки та перспективи подальших досліджень. Існуючі методики розрахунку ефективності виробництва неможливо використовувати на практиці. Ефективність повинна слугувати найважливішим орієнтиром для підприємців для вкладання інвестицій. Прикро, що особливості національної економіки робить цей показник зовсім непридатним для цього.

Ефективність виступає лише умовою ведення бізнеса. Для того, щоб ефективність була «доступна» для бізнесменів, потрібно іiї «корегувати» з урахуванням підприємницького ризику, бажання держави боротися 3 тіньовою економікою, захищати інвестиції. Слід відзначити, що сьогодні уряд країни розробив заходи по боротьбі 3 корупцією, підтримки бізнесу. Тому можна сподіватися, що разом з економічними реформами покращиться не тільки інвестиційна привабливість країни, але й буде розроблена нова методика розрахунку ефективності на підприємствах харчової промисловості.

\section{Література}

1. Краткий экономический словарь. Под ред. Ю. А. Беликова. - М. : Политиздат, 1987. - 398 с.

2. Продиус Ю. И. Экономика предприятия. - Харьков : «Одиссей», 2004. - 416 с.

3. Методи проведення спеціальних економічних розрахунків. Під ред. проф. Осіпова П. В. - Одеса : Друк, 2010. - 262 с.

4. Економіка харчової промисловості. За ред. проф. Кошелюка С.П. - К. : Вища школа, 1994. - 334 с.

5. Гончарук А. Г. Управление эффективностью деятельности предприятия. - Одесса : Астропринт, 2012. - 260 с.

6. Басюркіна Н. Й. Агропромислові формування в забезпеченні продовольчої безпеки. - Одеса : ІПРЕЕД НАН України, 2013. $-441 \mathrm{c}$

7. Самаева Ю. Ведение бизнеса: формальные полуулучшения. - Зеркало недели, 31 октября 2014 г.

8. Худицкий В. «Усушка и утруска» штрафных миллиардов. - Зеркало недели, 23 октября 2014 г.

9. Adam James. What Would a Manufacturing Renaissance Do to US Energy Intensity? April 3, 2013. [Електронний ресурс]. Режим доступу: http://www.greentechmedia.com/articles/read/energy-intensity-combined-heat-and-power-and-the-manufacturingrenaissance

10. Adebayo M. Shittu. Off-farm labour supply and production efficiency of farm household in rural Southwest Nigeria. [Електронний ресурс]. - Режим доступу: http://www.agrifoodecon.com/content/2/1/8

11. Luay Al-Khatteeb. Oil - A Question of Economics. October 30, 2014. [Електронний ресурс]. - Режим доступу: http://www. brookings.edu/research/opinions/2014/10/30-oil-a-question-of-economics -alkhatteeb

12. Germany, Italy, EU, China, and France Top Global Energy Efficiency Rankings. July 17, 2014. Ailis Aaron Wolf, (703) 2763265, The Hastings Group. [Електронний ресурс]. - Режим доступу: http://www.aceee.org/press/2014/07/germany-italy-eu-china-andfrance-to

13. Food Program. Food Economics. [Електронний ресурс]. - Режим доступу: http://www.sustainabletable.org/491/foodeconomics

14. EconomyPolitics 2nd Annual index of Economic Efficiency. [Електронний ресурс]. - Режим доступу: http://www. investingthesis.com/analysis-insights/economypolitics-2nd-annual-index-of-economic-efficiency/

Стаття надійшла 04.11.2014

Рецензент: Немченко В.В., доктор економічних наук, професор,завідувач кафедри обліку та аудиту Одеської національної академії харчових технологій 
Войтенко К.А.

аспирант

кафедра учета и аудита

Одесская национальная академия пищевых технологий

ул. Канатная, 112, г. Одесса, Украина, 65039

\title{
ПРОБЛЕМЫ ПОВЫШЕНИЯ ЭКОНОМИЧЕСКОЙ ЭФФЕКТИВНОСТИ ПРОИЗВОДСТВА НА ПРЕДПРИЯТИЯХ ПИЩЕВОЙ ПРОМЫШЛЕННОСТИ
}

Существуют различные методики определения эффективности производства, но они не приспособлены для пищевых предприятий и современных условий развития национальной экономики. Для того, чтобы эффективность была научно обосновано определена, необходимо её «корректировать» с учётом предпринимательского риска, желания государства защищать инвестиции и бороться с теневой экономикой. Деятельность предпринимателя направлена на защиту своей фирмы от рисков, угрожающих её прибыльности, эффективности.

Ключевые слова: эффективность производства, эффективность потребления пищевых продуктов, инвестиционный (предпринимательский) риск.

\author{
Voytenko K.A. \\ Postgraduate student \\ Department of Accounting and Auditing \\ Odessa National Academy of Food Technologies \\ Kanatnaya Street, 112, Odessa, Ukraine, 65039
}

\section{PROBLEMS OF INCREASING ECONOMIC EFFICIENCY IN THE FOOD INDUSTRY}

Abstract. Existing methods of calculating the efficiency of production cannot be used in practice. Efficiency should serve as an important guideline for enterprises for investment. It is pity that the characteristics of the national economy makes this figure unfit for food businesses. Existing motivational mechanism increasing efficiency should be supported by liability as employees and business ability of the State to protect businesses. In order for efficiency was determined scientifically accurate, it should be "corrected»with the business risk, the State's desire to fight the shadow economy. Activity entrepreneur aims to protect his company from the risks that threaten its profitability, efficiency. That is why the economic reforms will improve not only attractiveness but also will create a new method of determining the efficiency that would take into account the risks.

\section{References}

1. Kratkyy ekonomycheskyy slovar’. (1987). Pod red. Yu. A. Belykova. M.: Polytyzdat, 398 .

2. Prodyus Yu. Y. (2004). Ekonomyka predpryyatyya. Khar'kov: «Odyssey», 416.

3. Metody provedennya spetsial'nykh ekonomichnykh rozrakhunkiv. (2010). Pid red. prof. Osipova P. V. Odesa: Druk, 262.

4. Ekonomika kharchovoyi promyslovosti. (1994). Za red. prof. Koshelyuka S. P. - K. : Vyshcha shkola, 334.

5. Honcharuk A. H. (2012). Upravlenye effektyvnost'yu deyatel'nosty predpryyatyya. Odessa: Astroprynt, 260. iny, 441 .

6. Basyurkina N. Y. (2013). Ahropromyslovi formuvannya v zabezpechenni prodovol'choyi bezpeky. Odesa: IPREED NAN Ukray-

7. Samaeva Yu. (2014). Vedenye byznesa: formal'nye poluuluchshenyya. Zerkalo nedely, 31 oktyabrya.

8. Khudytskyy V. (2914). «Usushka y utruska» shtrafnukh myllyardov. Zerkalo nedely, 23 oktyabrya.

9. Adam James. What Would a Manufacturing Renaissance Do to US Energy Intensity? April 3, 2013. Elektronnyy resurs. Rezhym dostupu: http://www.greentechmedia.com/articles/read/energy-intensity-combined-heat-and-power-and-the-manufacturing-renaissance

10. Adebayo M Shittu.Off-farm labour supply and production efficiency of farm household in rural Southwest Nigeria Elektronnyy resurs. Rezhym dostupu: http://www.agrifoodecon.com/content/2/1/8

11. Luay Al-Khatteeb. Oil - A Question of Economics. October 30, 2014. Elektronnyy resurs. Rezhym dostupu: http://www.brookings.edu/research/opinions/2014/10/30-oil-a-question-of-economics-alkhatteeb

12. Germany, Italy, EU, China, and France Top Global Energy Efficiency Rankings. July 17, 2014. Ailis Aaron Wolf, (703) 2763265, The Hastings Group. Elektronnyy resurs. Rezhym dostupu: http://www.aceee.org/press/2014/07/germany-italy-eu-china-andfrance-to

13. Food Program. Food Economics. Elektronnyy resurs. Rezhym dostupu: http://www.sustainabletable.org/491/food-economics

14. EconomyPolitics 2nd Annual index of Economic Efficiency. Elektronnyy resurs. Rezhym dostupu: http://www.investingthesis. com/analysis-insights/economypolitics-2nd-annual-index-of-economic-efficiency/ 